\title{
Promoting the facilities management profession in the project development phase of high-rise buildings in Sri Lanka
}

\author{
Nayanthara de Silva
}

\begin{abstract}
Purpose - The Facilities Management (FM) profession is now established in most developed countries and in few developing countries such as Singapore and Hong Kong. However, with rapid mushrooming of high rise buildings, which are known to be complex, the role of a facilities manager may require to be extended even up to the project briefing stage. This paper aims to highlight the importance of consulting a facilities manager during the project development phase of high rise buildings in Sri Lanka.
\end{abstract}

Design/methodology/approach - The methods of data collection used in this study were site observations and interviews. The data from site observations were collected from 67 high rise residential and commercial buildings. While doing the site observations or some on occasions after the site observations, the facilities managers or building managers and maintenance managers of these buildings were interviewed to gather further detailed information.

Findings - This paper highlights 15 critical maintainability problems, which originated during the development phase. It was found 26 significant factors which would have been emphasized during the development phase by a facilities manager to reduce the occurrence of such problems during the phase of occupancy.

Research limitations/implications - There were few qualified facilities managers involved during the data collection process due to lack of qualified facilities managers in Sri Lanka.

Originality/value - The paper provides useful information to the facilities managers and clients/users on maintainability problems related to high rise buildings. It also emphasize the importance of the involvement of facilities managers at the development phase of high rise buildings in order to minimize their maintainability problems faced during the phase of occupancy.

\section{Introduction}

Generally, various groups of people are involved at different stages of the development phase of a high rise building. For instance, a consultant is involved with a project from the project start up stage to the post completion stage, whereas a contractor is appointed at the award of contract stage and continues up to the post completion stage. In addition, there are many professionals such as architects, engineers, quantity surveyors, and various other parties such as suppliers, specialist contractors, etc., who are involved at different stages of a project. In general, in the traditional practice, these sets of people are not responsible for the building after commissioning it. However, this completed building needs to be maintained effectively throughout its design life. This role is taken over by a facilities manager who is appointed during or after commissioning of the building, in general.

The main role of a facilities manager thereafter is the conversion of this physical product into a suitable and habitable built environment (Alexander, 1994; Atkin and Brooks, 2002; Barret and Baldry, 1995; Grimshaw, 2003; Kelly et al., 2005; Ventovuori et al., 2007). Most importantly, this environment needs to be maintained throughout the building's service life. In this process, successful management of the facility consistently depends on the cost effectiveness of its maintainability process. These cost effective decisions may be initiated from early development phase for efficient maintainability of the facility (Chew and De Silva. 2003a\&b; De Silva and Ranasinghe, 2010). Facilities managers can contribute significantly in the delivery of such effective decisions at this point, based on their practical exposure to maintainability problems that are faced during the phase of occupancy (De Silva and Ranasinghe, 2010). But there is little evidence reported of acquiring benefits from a facilities manager during the project development phase to consign the foundation for maintainable deliverables (Nutt, 1993; Preiser, 1995; Hinks et al., 1999; McLennan, 2000; Her and Russell, 2002; Kelly et al., 2005).Therefore, maintaining a high rise building can become an expensive and complex affair (pilot study report by Building Construction Authority (BCA), 2000; Boussabaine and Kirkham, 2004; Wimalaratne, 2005; Central Bank of Sri Lanka, 2007). These higher budgetary require- 
ments for maintenance have originated from the early stages of design and construction (Assaf et al., 1995; Al-hammad et al., 1997; Adejimi, 2005).

Until recent, the early consideration of maintainability issues was not considered as a common practice in the Sri Lankan construction industry. This has been escalated a number of maintainability issues of high rise buildings (De Silva and Ranasinghe, 2010). Further, it is likely to cause serious issues in the near future especially with respect to larger numbers of high rise buildings mushrooming in the city of Colombo and suburbs. Therefore, this paper focuses on emphasizing the benefits of FM profession's enlistment during the project development phase to reduce such maintainability issues which in turn minimize the maintenance budgets.

\section{Benefits of Enlisting a Facilities Manager in the Development Phase of High Rise Buildings}

Strategic facilities management is focused to provide maximum comfort to the occupants at a minimum cost. Thus, if this task starts during the project planning stage, the "pro active" facilities manager can obtain the overall control towards taking correct decisions for cost effective maintainability strategies (Her and Russell, 2002; Stoy and Kytzia, 2006; Newton and Christian, 2006). On the other hand, facilities managers are the "keepers" of databases and information systems that contain valuable operational and maintenance information on different building types (Preiser, 1995). This information from facilities managers enriched with their vast store of practical knowledge and experience and the feedback from users of the building on operational and maintenance problems, are excellent inputs for the designers in order to develop "highly maintainable" buildings (Buys and Nkado, 2006). Thus the facilities manager could be the "pathway" for providing such feedback and for persuading designers to take correct design decisions on any facilities management issue, in order to make life easier for all stakeholders.

In many instances, design related maintainability problems are highlighted due to the lack of communication between the designers and the facilities managers to seek advice about potential problems in their designs (Chong and Low, 2006). A typical example is, lack of space provided in the service ducks for services of most of high rise buildings. Therefore, there is much evidence to demonstrate that poor design decisions continue to be repeated in every new building (Zubairu, 2001; Andi and Minato, 2004). Further, Chong and Low (2006) found that a facilities manager has very little control (i.e. about $4 \%$ ) during the stage of occupancy to minimize maintainability problems and defects occurring from such deficiencies, whereas designers can take control (i.e. about $84 \%$ ), with the support of a facilities manager, over the minimization of these problems.
Further, LCC assessment of facilities management during the project's early stage is another benefit. The cost components for LCC assessment can be compromised with repair and replacement cost, cleaning and operational costs, refurbishment cost, and downtime costs. However, it has not yet achieved the status of a common tool among facilities mangers due to a lack of practical knowledge and awareness. Further, not having a common LCC calculation procedure nor a software programme is another barrier for popularizing this practice among the facilities managers. But, there is some evidence of improving LCC associated, with the increasing number of public private partnership projects (Pelzeter, 2007).

Similar to practices in many other countries', there is no established mechanism in Sri Lanka to haul out benefits from enlisting the facilities managers at the development phase to minimize long term maintainability problems of buildings. This situation has been created many maintainability problems such as no accessibility or sufficient spaces provided in the buildings for maintenance work.

\section{Research Methodology and Analysis}

The extensive literature search was carried out to identify the critical factors related to the development phase for maintainability problems. Further, a field survey was conducted to explore such existing problems faced by the users, facilities managers and the maintenance managers in high rise buildings. A sample of buildings for field survey was selected based on the available listings of high rise buildings in the Urban Development Authority, Colombo Municipal Council and the personal contacts. The sample was consisted with 67 residential and commercial buildings and the age group of these buildings was varied from 3 years (i.e. above the age of defect liability period) to 30 years (i.e. below the age of a major refurbishment). The inspections were made with the support of facilities/maintenance managers to observe the existing maintainability problems. Subsequent interviews were conducted with these experts to explore criticality of above factors for their problems. A 7 point "Likert" scale was used to elicit the criticality of these factors.

Fifteen commonly occurred maintainability problems were observed during the field survey. The mean ratings of their frequencies were used to rank these identified problems (Table 1). Water seepage due to waterproofing defects was the most frequent defects in high rise buildings. Further, 26 significant factors were established using the t-test from the experts responses, for occurring these problems in these buildings (Table 2). T-test was carried out using Software Package for Social Science (SPSS) version 10 and the significance level was considered as the 95th percentile level. 
Table 1: Frequent maintainability issues related to increasing maintenance costs

\begin{tabular}{|c|c|c|c|}
\hline No & Defects & Mean Rating & Rank \\
\hline 1 & Waterproofing defects & 4.30 & 1 \\
\hline 2 & Doors, windows \& joinery defects & 3.73 & 2 \\
\hline 3 & Piping/ plumbing \& duct work defects & 3.60 & 3 \\
\hline 4 & Tile defects & 3.23 & 4 \\
\hline 5 & Sanitary ware, fittings \& jointing defects & 3.13 & 5 \\
\hline 6 & Defects in claddings \& curtain walls & 3.10 & 6 \\
\hline 7 & Defects in ceiling components & 3.07 & 7 \\
\hline 8 & Defects in services & 3.00 & 8 \\
\hline 9 & Plaster defects & 3.03 & 9 \\
\hline 10 & Biological \& chemical attacks & 2.63 & 10 \\
\hline 11 & Defects in masonry (brick/ block) walls & 2.73 & 11 \\
\hline 12 & Paint defects & 2.80 & 12 \\
\hline 13 & Defects in structural concrete & 2.27 & 13 \\
\hline 14 & Defects in floor components & 2.33 & 14 \\
\hline 15 & Defects in structural steel & 1.40 & 15 \\
\hline
\end{tabular}

\section{Maintainability Problems in Managing of High Rise Buildings: Discussion Using Building Fabric Problems}

Due to the failure to address facilities management problems right from the design stage, facilities managers/owners/users of high rise buildings face many difficulties with their nature of difficult maintainability. Further, many latent building defects such as water seepage, failures of finishing materials, staining, etc., waste in energy, high rate of deterioration, etc., occur as a result (Chew and De Silva, 2003a\&b; Chew et al., 2004; Chew and Tan, 2003a\&b; Wong and Hui, 2005; Flores-Colen et al., 2008). Similar problems were observed in high rise buildings in Sri Lanka, and they were ranked based on the frequency of their occurrence. Table 1 summarizes 15 critical maintainability problems.

Twenty six significant factors related to design phase for these critical maintainability problems were established from the views of the experts including facilities managers, building managers and maintenance managers of these buildings. These are discussed under six groups as listed in Table 2.
The lack of attention for future maintenance requirements is the most critical factor. The frequency and the method of maintenance and cleaning, complexity of the building and the availability of components; technology and skills were found to be important. For instance, it was revealed that the costs for cleaning and janitorial processes were more than $80 \%$ of the total building maintenance costs in some condominiums of Sri Lanka, due to lack of provisions for the easy procedures. In some cases, facilities managers used alternative methods for cleaning the external façades or left unattained, due to non practicability of the recommended methods. Similarly, Chew et al., (2008) has expressed that cleaning costs can more effectively be controlled and minimized during the design stage than in the phase of occupancy, by providing useful features in the design. The complexity of the building, level of usage and nature of usage are also critical for increased difficulty of the maintenance and cleaning. For example, a basement car park floor beneath the swimming pool and the garden was leaking, in a particular condominium. But, the impossibility of shutting down of the below level car park and the above level garden to carry out the repair work due to heavy usage of both locations, was left the defect unattended. 
Table 2: Critical design related maintainability problem causing factors

\begin{tabular}{|c|c|c|c|}
\hline Factors & Mean & t - test & Sig. \\
\hline 1. Consideration of future maintenance requirements & 6.000 & 12.615 & 0.000 \\
\hline Frequency and the method of cleaning required & 4.882 & 5.135 & 0.000 \\
\hline Frequency and the method of maintenance required & 4.869 & 4.702 & 0.000 \\
\hline Complexity of the building (shape) & 4.885 & 4.658 & 0.000 \\
\hline $\begin{array}{l}\text { Availability of materials/component/technology and } \\
\text { skills }\end{array}$ & 4.738 & 3.646 & 0.001 \\
\hline Level of usage & 4.984 & 5.981 & 0.000 \\
\hline Nature of usage & 4.46 & 2.941 & 0.005 \\
\hline $\begin{array}{l}\text { 2. Involvement of facilities management personnel in the } \\
\text { design phase }\end{array}$ & 5.984 & 11.942 & 0.000 \\
\hline \multicolumn{4}{|l|}{ 3. Accessibility of future maintenance } \\
\hline $\begin{array}{l}\text { Number of access system needed for cleaning \& } \\
\text { maintenance }\end{array}$ & 5.869 & 11.253 & 0.000 \\
\hline Accessibility to the roof & 5.541 & 11.211 & 0.000 \\
\hline Adequate space for regular maintenance \& cleaning & 5.705 & 10.952 & 0.000 \\
\hline Accessibility to underground drainage systems & 5.853 & 10.605 & 0.000 \\
\hline Accessibility to services of the building & 5.853 & 10.511 & 0.000 \\
\hline $\begin{array}{l}\text { Provision for temporary access system for cleaning \& } \\
\text { maintenance }\end{array}$ & 5.803 & 9.974 & 0.000 \\
\hline Accessibility to exterior walls \& windows & 5.639 & 8.321 & 0.000 \\
\hline Accessibility to basements & 5.030 & 4.69 & 0.000 \\
\hline Attachment of permanent fixtures & 5.246 & 7.721 & 0.000 \\
\hline \multicolumn{4}{|l|}{ 4. Considerations of climatic conditions } \\
\hline $\begin{array}{l}\text { Suitability of material/ component for exposure } \\
\text { conditions }\end{array}$ & 5.230 & 7.409 & 0.000 \\
\hline Durability (service life) of components and materials & 5.131 & 5.607 & 0.000 \\
\hline $\begin{array}{l}\text { Suitability of the structure (design) for tropical climatic } \\
\text { conditions }\end{array}$ & 5.115 & 5.822 & 0.000 \\
\hline Building orientation & 4.885 & 5.578 & 0.000 \\
\hline Level of exposure to the external climate & 4.492 & 2.68 & 0.009 \\
\hline 5. Consideration of future maintenance budget & 5.606 & 7.11 & 0.000 \\
\hline \multicolumn{4}{|l|}{ 6. Sufficient detailing } \\
\hline $\begin{array}{l}\text { Embedded services within the building elements (pipe } \\
\text { lines, ducts) }\end{array}$ & 5.246 & 5.478 & 0.000 \\
\hline Provision of joints and their poor detailing & 5.082 & 5.334 & 0.000 \\
\hline Load bearing capacity for current and future usage & 5.098 & 4.961 & 0.000 \\
\hline
\end{tabular}

Direct involvement of a facilities manager during the development phase was suggested by the experts, though this is not a common practice in the local industry. They showed that the decisions of facilities managers are very important to design highly maintainable buildings with zero maintainability issues. In contrast to appointing a facilities manager in the development phase, a team of members in the development phase was appointed for the maintenance crew, in some high rise buildings. Brochner (2008) has also indicated the advantages of continuing the role of the contractor through to the post construction stage in order to get the same benefits by a facilities manager. In the UK, the government policies are developed integrating strong ties between construction and facilities management. For instance, Private Finance Initiative (PFI) contracts, where design, construction, finance and operation of projects are consolidated, have demonstrated the strong links between construction and operation (Bennett and lossa, 2006). However, in both situations, what emphasized was, employing a same person or group throughout the life cycle of a building, integrating the two phases; project development and phase of occupancy or having 
a continuous relationship between the clients. In fact, Cacciatori and Jacobides (2005) found the positioning of construction contractors in UK as facilities managers. However, the integration of FM in the development phase is not yet established in Sri Lanka. This may be due to lack of awareness of this profession in the local industry due to its adolescent stage. Further, maintainability of buildings was not become a heavy burden until recent, with the aging and development large number of high rise buildings. This may also be another reason for unpopularity of the FM profession in Sri Lanka. There is no carder position for a facilities manager in most of the government buildings. On the other hand, most of the responsibilities of a facilities manager were carried out by an outsourced team headed by a maintenance personal, in many private organizations. However, the existing situation is to be immediately changed, and further, the enlisting of facilities managers to the development phase of buildings should be encouraged, before maintainability of such buildings would become a burden to the country.

The accessibility plays a vital role in the maintenance process of high rise buildings. Provisions for easy access for the various building elements and the components such as the external wall, roof, basement, and services can make the maintenance processes efficient. These provisions may need to consider access ways, access methods (permanent or temporary), and also a number of different access systems needed to cover the entire building. For instance, some complex shapes of the external façade, embedded services, and insufficient spaces provided may hinder the easy accessibility for the maintenance activities. This in turn increases the maintenance cost by hiring special access systems, different systems or due to the escalating number of defects created under these circumstances. In some situations, the access for maintenance was not allowed due to security reasons in the country. Therefore, designs are expected to meet relevant standards and legal requirements. Further, adequate safety access should be provided for maintenance staff. This has been highlighted by many authors and is also incorporated into many codes of practices related to designing safety in accessibility (eg. BSI, 1986; BSI, 1991; BSI, 2001; PWD-Singapore, 1995; NASA facilities engineering handbook, cited in Her and Russell, 2002; CDM regulations, 1995cited in Craddock and Marino). On the other hand, more often, accessibility for differently able people and elderly people is neglected (Ormerod and Newton, 2005). Therefore, having a system to evaluate the building designs for various levels of accessibility is equally important as similar as the above codes of practices (Wu et al., 2007).

The environmental conditions under the tropical climate is characterised by frequent change in temperature and pressure, high humidity and abundant rainfall. However, depending on the buildings' loca- tion, different zones such as industrial, urban, rural or coastal area can be evaluated under macro environment, whereas degree of exposure to the external climate, level and the nature of the usage, orientation of the building, and its complexity of the shape can be considered under micro environment, when designing for high maintainability (De Silva and Ranasinghe, 2010). Similarly, the performance of material, design, and the level of exposure were indicated to be important for the local conditions. For example, some selants are not performing well under the tropical conditions and noticed early deterioration in some buildings. Further, water leakages of external façades were identified under this situation. Therefore, characteristics of materials such as lifespan, sustainability, compatibility and maintainability, architectural design and orientation are important factors to be considered to evaluate the durability under the various deterioration mechanisms (Shohet et al., 2002\&2004; Teo and Harikrishna, 2006; Yong, 2007). The facilities managers have good understanding of such data by experience, and therefore, their feedback in this regard can be used to take the correct decisions at the early stages.

Consideration of funding for future maintainability is a critical factor for its management of facilities. It was identified that, some of the earliest high rise buildings were left with no maintenance due to insufficient budget for their maintenance. Projection for realistic maintenance budgets to be prepared to evaluate future maintainability of the building. Whole life costing (WLC) assessments can be proposed for this task (Engelhardt et al., 2002; Kirkham et al., 2004; Junnila et al., 2006).

Proper detailing for structural strength, tightness requirements, joints, interconnections, etc., can reduce the risk of early failures during the service life (Chew et al., 2004; Adejimi, 2005). Similarly, many maintainability problems were identified due to lack of such detailing of high rise buildings. Detailing of waterproofing, joints for accommodating the movements and drainage detailing for ground water seepage are some critical examples. Further, some detailing such as loading conditions is to be importantly considered for the future requirements for some buildings. For instance, the dead load from the escalated number of documents in one of the office buildings is at the maximum loading capacity of the floor and hence its management is facing a critical situation of handling the documents.

\section{Conclusions and Recommendations}

With the ever increasing high rise buildings such as shopping complexes, condominiums, office complexes etc., in which their performance being highly depended on its maintainability, the demand for managing these facilities have created a niche market for facilities managers. However, with lack of FM inputs 
at the development phase of these high rise buildings, there were many maintainability problems noted. Among them, 15 critical problems were identified. Further, 26 significant factors for the occurring these problems were established and discussed under six groups.

The proper enlisting of facilities managers will enable organizations to provide the right environment with no maintainability problems for conducting their core businesses on a cost effective way. Putting foundation for "value for money service" should be stated at the beginning of the development phase of these buildings. Therefore, the service of a facilities manager as a consultant to the developer during this phase is important. However, this is not an established practice in the local construction industry leaving many difficulties caused by many maintainability problems as discussed, resulting in increased difficulty of the maintenance during the phase of occupancy of a building. Lack of awareness of the FM profession due unavailability of locally qualified facilities managers, may be the main reason behind the unpopularity of the profession and its benefits. On the other hand, the demand for facilities managers has not been shown high till recent years, due to slow growth of modern high rise buildings. However, this situation is being changed creating a number of positions for facilities managers with an increased number of high rise buildings. Therefore, the findings of this research can be taken as a momentum to take pro active measures to improve the "quality of life" of the buildings at the early development phase, by integrating the field of facilities management. The followings are some recommendations to enhance and establish this profession in the industry by encouraging:

- Institutions to start degree programmes in the area of facilities management.

- Professional bodies to start to offer profes sional qualifications to recognize the profes sion.

- Clients/ project managers to consult a facili ties manager throughout the project process and to also allocate a budget in the procure ment system to recruit such professionals.

- Clients to evaluate the project feasibility based on life cycle cost approach.

- Government/ Authorities to regulate the need of the approval of a charted facilities manger upon some facilities in large projects such as condominiums, apartments, etc.

\section{Reference}

Adejimi, A. (2005) Poor building maintenance in $\mathrm{Ni}$ geria: are architects free from blames?, Pro ceedings of ENHR International conference on Housing: New Challenges and Innova tions in Tomorrow's Cities, Iceland, 29th June - 3rd July, 2005.

Alexandra, K. (1994) A strategy for facilities manage ment, Facilities, 12(11), pp. 6-10.

Al-Hammad, A., Assaf, S. and Al-Shihah, M. (1997) The effect of faulty design on build ingmaintenance, Journal of Quality in Mainte nance, 3(1), pp.29-39.

Andi and Minato, T. (2004) Representing causal mechanism of defective designs: exploration through case studies, Construction Manage ment and Economics, 22, pp. 183-192.

Assaf, S, Al-Hammad, A and Al-Shihah, M. (1995) The Effect of Faulty Construction on Building Maintenance, Building Research and Infor mation, 23 (3), pp.175-181.

Atkin, B. and Brooks, A. (2002) Total Facilities Man agement, The Further Education Funding Council and Blackwell Science Ltd., London.

Barrett, P. and Baldry, D. (1995) Facilities Manage ment: Towards Best Practice, Blackwell Sci ence, Oxford.

Bennett, J. and lossa, E. (2006) Building and man aging facilities for public services, Journal of Public Economics, 90(10/11), pp. 21432160.

Boussabaine, A.H., Kirkham, R.J. and Grew, R.J. (1999) Modelling total energy costs of sports centres, Facilities, 17(12/13), pp. 452-461.

British Standards Institute (1986) BS 8210: Guide to Building Maintenance Management, Brit ish Standards Institute, UK.

British Standards Institute (1991) BS 8213: Win dows, doors and rooflights. Code of prac tice for safety in use and during cleaning of windows and doors (including guidance on cleaning materials and methods), British Standard Institution, UK.

British Standards Institute (2001b) BS 8300: De sign of buildings and their approaches to meet the needs of disabled people, British Standards Institute, UK. 
Brochner, J. (2008) Construction contractors inte grating into facilities management, Facilities, 26(1/2), pp. 6-15.

Building Construction Authority (2000) Enhancing Maintainability of Buildings- Pilot Study $\mathrm{Re}$ port, Building Construction Authority, Singa pore.

Buys, F. and Nkado, R. (2006) A survey of mainte nance management systems in South Afri cantertiary educational management, Con struction Management and Economics, 24, pp. 997-1005.

Cacciatori, E. and Jacobides, M.G. (2005) The dy namic limits of specialization: vertical integra tion reconsidered, Organization Studies, Vol. 26 No. 12, pp. 1851-83.

Central Bank of Sri Lanka (2007), Annual Report - 2007, Central Bank of Sri Lanka, Colombo, available at http://www. cbsl.gov.lk/ info/10_publication/p_1.htm, [ac cessed on 20th January 2008].

Chew, M.Y.L. and De Silva, N. (2003a) Maintainabil ity problems of wet area in high-rise residen tial building in Singapore, Building Research and Information, 31(1), pp. 60-69.

Chew, M.Y.L. and De Silva, N. (2003b) Benchmarks to minimize water leakages in basements, Structural Survey, 21(4), 131-145.

Chew, M.Y.L. and Tan, P.P (2003a) Staining of Fa cades, World Scientific publishing: Singa pore.

Chew, M.Y.L. and Tan, P.P. (2003b) Facade stain ingarising from design features, Journal of Construction and Building Materi als, 17(3), pp.181-7.

Chew, M.Y.L, De Silva, N. and Tan, S.S. (2004) Maintainability of wet areas of non-residen tialbuildings, Structural Survey, 22(1), pp. 39-52.

Chew, M.Y.L., Wong C.W., Shah K.W., Tan P.P, Chen Y.u, Tan J.J., Wei A.A.Z., Quang J.L.V., Trial Test on Photocatalytic Anti-stain ing Coatings on Facade and the Develop ment of a Stain Index and Prototype Onsite Non-destructive Diagnostic Tool to As sess the Level of Staining of a Façade, Avail able at http://www.bca.gov.sg/Researchln novation/others/photocatalytic.pdf, accessed on 16th May 2008.
Chong, W-K. and Low S-P. (2006) Latent building defects: causes and design strategies to pre vent them, Journal of Performance of Con structed Facilities, 20 (3), pp. 213-221.

Craddock, P.A. and Marino, B. M., Designing Safe Access for Maintenance and Repair, available at http:// www.ciihk.org.hk/conference2007/ files/S4-04\%20Ms\%20Barbara\%20Marino. pdf, accessed on 16th March 2009.

De Silva, N. and Ranasinghe, M. (2010) Maintain ability risks of condominiums in Sri Lanka, Journal of Financial Management of Proper ty and Construction, 15(1), pp. 41-60.

Engelhardt, M., Skipworth, P., Savic, D.A., Wal ters, G.A. and Saul, A.J. (2002) Determin ing maintenance requirements of a water dis tribution network using whole life costing, Journal of Quality in Maintenance Engineer ing, 8(2), pp. 152-164.

Flores-Colen, I., De Brito, J. And De Freitas, V.P. (2008) Stain in facades' rendering - diagno sis and maintenance techniques' classifica tion, Construction and Building Materials, 22, pp. 211-221.

Grimshaw, R.W. (2003) FM: the professional inter face, Facilities, 21(3/4), pp. 50-57.

Her, B.M. and Russell, J.S. (2002) Maintainability implemented by third-party contractor for public owner, Journal of Management in Engineering, 18(2), pp. 95-102.

Hinks, J., Kelly, J. and McDougall, G. (1999) Fa cilities Management and the Charted Survey: An Investigation of Charted Survey ors' Perception, RICS Research, Coventry.

Junnila, S., Horvath, A. and Guggemos, A.A. (2006) Life-cycle assessment of office build ings in Europe and the United States, Journal of Infrastructure Systems, 12(1), pp10-17.

Kelly, J., Hunter, K., Shen, G. and Yu, A. (2005) Briefing from a facilities management per spective, Facilities, 23(7/8), pp. 356-367.

Kirkham, R.J., Alisa, M, Da Silva, A.P., Grind ley, T. and Brondsted, J. (2004) Euro lifeform: An integrated probabilistic whole life cycle cost and performance model for buildings and civil infrastructure, Proceedings of The International Construction Research Conference of the Royal Institution of Charted 
Surveyors,Leeds Metropolitan

University., available at: www.rics.org/

NR/rdonlyres/4F8861E3- CF0C-

431F-85D983B9BB86/0/ eurolife.pdf

(accessed on 27th December 2008).

Newton, L.A. and Christian, J. (2006) Impact of Quality on Building Costs, Journal of Infra structure Systems, pp.199-206.

Nutt, B. (1993) The strategic brief, Facilities, 11(9), pp. 28-32.

Ormerod, MG. and Newton, R.A. (2005) Briefing for accessibility in design, Facilities, 23(7/8), pp. 285-294.

Pelzeter, A. (2007) Building optimization with life cy cle costs - the influence of calculation meth ods, Journal of Facilities Management, 5(2), pp. 115-128.

Preiser, W.F.E. (1995) Post-occupancy evaluation: how to make buildings work better, Facilities, 13(11), pp. 19-28.

Public Works Department- Building Control Divi sion (1995) Code on Barrier-free Accessibil ity in Building, Building Control DivisionPWD, Singapore.

Shohet, I.M., Puterman, M. and Gilboa, E. (2002) Deterioration patterns of building cladding components for maintenance management, Construction Management and Economics, 20, 305-314.

Shohet, I.M. and Paciuk, M. (2004) Service life pre diction of exterior cladding components un der standard conditions, Construction Man agement and Economics, 22, 1081-1090.
Stoy, C. and Kytzia, S. (2006) Occupancy costs: a method for their estimation, Facilities, 24(13/14), pp. 476-489.

Teo, E. A. and Harikrishna, N. (2006) A quantita tive model for effective maintenance of plas tered and painted façades, Construction Management and Economics, 24, pp.12831293.

Ventovuori, T., Lehtonen, T., Salonen, A. and Nenonen, S. (2007) A review and classifica tion of academic research in facilities man agement, Facilities, 25(5/6), pp. 227-237.

Wimalaratne, A. (2005) The role of 'Management Corporation Concept' in housing apartments, News paper article, The Island-06th May 2005.

Wong J.T.Y and Hui, E.C.M. (2005) Water seep age in multi-storey buildings, Facili ties, 23(13/14), pp. 595-607.

Wu, S., Lee, A., Tah, J.H.M. and Aouad, G. (2007) The use of a multi-attribute tool for evaluat ingaccessibility in buildings: the AHP ap proach, Facilities, 25(9/10), pp. 375-389.

Yong, M.E. (2007) Dampness penetration problems in granite buildings in Aberdeen, UK: causes and remedies, Construction and Building $\mathrm{Ma}$ terials, 21, pp. 1846-1859.

Zubairu S.N. (2001) The Most Frequently Recurring Maintenance Problems in Government Of fice Buildings in Nigeria, NIAJ, ii, pp. 8-12. 